\title{
Increase of immigrants in emerging countries: free public healthcare and vaccination as preventive measures in Brazil
}

\author{
Aumento de imigrantes em países emergentes: \\ saúde pública gratuita e vacinação como \\ medidas preventivas no Brasil
}

\section{Aumento de inmigrantes en países emergentes: atención a la salud gratuita y vacunación como medidas preventivas en Brasil}

\author{
Dennis Minoru Fujita 1,2 \\ Felipe Scassi Salvador 3 \\ Giselle Pacífico Sartori Damião 1 \\ Gerusa Maria Figueiredo 1 \\ Luiz Henrique da Silva Nali 3
}

doi: 10.1590/0102-311X00228118

\section{Introduction}

In 2018, 65.6 million individuals around the world were forcibly displaced, according to the United Nations High Commissioner for Refugees (UNHCR), who were divided in 22.5 million refugees, 10 million stateless people and 189,300 resettled refugees. The majority of refugees (55\%) were from three countries: South Sudan, Afghanistan and Syria 1.

The reinforcement of cross-border policies in developed countries 2,3 lead refugees to seek emerging and even poor nations ${ }^{4}$ as a new option due to the weak border surveillance and flexible entrance polices for foreigners which allow them to remain in these countries while awaiting the legalization of their stay.

Brazil is one of these destinations for immigrants and refugees. The estimated population of immigrants in Brazil is 669,187, with a 160\% increase from 2010 to 2016 (Table 1) 5.

The number of asylum claims in the country increased to 33,865 , but only 473 were approved in 2017, a low rate in 5 years (Table 2). The main emissive countries (Table 3) of refugees to Brazil are Bolivia (15,753 in 2010), Haiti (34,770 in 2014) and Venezuela (17,865 in 2017).

\section{Health public policies for immigrants in Brazil}

Legal immigrants in Brazil receive the same healthcare as free medical assistance including preventive measures such as vaccination, pre-natal care and other protective clinical services offered by the Brazilian Unified National Health System (SUS) 6, the free care system established by the Brazilian Government.

In addition, illegal immigrants in Brazil are not totally out of this healthcare system ${ }^{7}$, receiving treatment for some illnesses, such as tuberculosis, and even other clinical and surgery procedures such as obstetric care.

Birth in Brazil is a cessionary condition that provides Brazilian citizenship to foreigner parents, explaining the increase in childbirths in Brazilian hospitals in the country's borders 8,9.
1 Instituto de Medicina Tropical de São Paulo, São Paulo, Brasil.

2 Instituto Federal de Educação, Ciência e Tecnologia de São Paulo, São Paulo, Brasil. 3 Universidade de Santo Amaro, São Paulo, Brasil.

Correspondence D. M. Fujita Instituto de Medicina Tropical de São Paulo. Av. Dr. Enéas Carvalho de Aguiar 470, São Paulo, SP 05403-000, Brasil. dmfujita@usp.br 


\section{The current immigration flow to Brazil}

\section{Bolivians}

The major group of immigrants (legal and illegal) from poor countries in Brazil are the Bolivians ( 90,000 in the state of São Paulo) 10, who arrive by land crossing the borders in the state of Mato Grosso (city of Corumbá). Chagas disease 11 and tuberculosis 7 are reported to be the main chronic infectious diseases of Bolivian immigrants.

Tuberculosis in Bolivian immigrants might be explained by their precarious life conditions, with some of them being also subjected to slavery work. Many of them have fled to Brazil, with the state of São Paulo featuring the greatest incidence of Bolivian immigrants 12 .

\section{Haitians}

Haitian refugees come to Brazil by land, crossing the borders in the North (states of Acre, Rondônia and Amazonas) and Central regions. According to the 2014 Annual Report on Social Information (RAIS; http://obmigra.mte.gov.br/index.php/component/k2/itemlist/category/42, accessed on 11/ Apr/2018), Haitians established themselves in the formal labor market in the South region $(59.2 \%-$ mainly in the state of Santa Catarina), Southeast region (28.2\% - mainly in São Paulo) and in other regions $(12.6 \%)$.

\section{Table 1}

\begin{tabular}{lc}
\multicolumn{2}{l}{ Immigrants and refugees in Brazil: legally entry. } \\
\hline Year & Population \\
\hline 2010 & 61,906 \\
2011 & 79,617 \\
2012 & 89,397 \\
2013 & 118,165 \\
2014 & 122,328 \\
2015 & 103,641 \\
2016 & 94,133 \\
Total & 669,187 \\
\hline
\end{tabular}

Source: Brazilian Ministry of Justice 23.

Table 2

Immigrants and refugees in Brazil: asylum.

\begin{tabular}{lcc}
\hline Year & Claims & Approved \\
\hline 2010 & 966 & 126 \\
2011 & 3,220 & 124 \\
2012 & 4,022 & 199 \\
2013 & 17,631 & 691 \\
2014 & 28,385 & 2,288 \\
2015 & 28,670 & 1,231 \\
2016 & 10,308 & 886 \\
2017 & 33,865 & 473 \\
\hline
\end{tabular}

Source: Brazilian Ministry of Justice 23. 
Table 3

Immigrants and refugees in Brazil: main emissive countries.

\begin{tabular}{cccc}
\hline Year & Haiti & Venezuela & Bolivia \\
\hline 2010 & 442 & 4 & 9,965 \\
2011 & 2,991 & 8 & 12,783 \\
2012 & 6,301 & 9 & 11,331 \\
2013 & 17,991 & 64 & 11,586 \\
2014 & 34,770 & 272 & 6,546 \\
2015 & 5,364 & 1,101 & 5,154 \\
2016 & 6,010 & 4,434 & 5,154 \\
2017 & 2,362 & 17,865 & \\
\hline
\end{tabular}

Source: Brazilian Ministry of Justice 23 .

Some studies have described that Haitian immigrants were in good health conditions upon their arrival in Brazil (in the Amazonas State) 13,14, leading us to the "healthy migrants" theory, because even after an exhausting journey (including the adverse conditions of their country), they were in good health conditions upon arriving at the receiving country, sometimes free of chronic diseases such as diabetes, hypertension and others.

However, we may consider two groups of immigrants that come to Brazil. The first is composed by people with a considerable social condition, with good access to better education or financial support to escape or to seek new perspectives, which corroborates the previous concept.

They are responsible for stimulating the flow of people from one country to another, becoming the alert signal for the improvement of national surveillance systems to prepare the country's protective measures and infrastructure to receive the second group of immigrants, usually composed of people who used to be in worse socioeconomical conditions in their homeland, and who are thus more susceptible to local endemic diseases 15.

For example, after four years of intensive migration from Haiti, there is an impressive peak in the flow of displacements in 2014 ( $\mathrm{n}=34,770$ Haitians), and the concomitant introduction of the Asian genotype of the Chikungunya virus (the circulating strain in the Caribbean region since 2013) in Brazil by illegal Haitian or Dominican immigrants in the extreme North region of the country 16.

Another study detected a silent infectious disease (lymphatic filariasis) in ten Haitian immigrants in Chapecó (state of Santa Catarina) 17. The constant healthcare assistance for immigrants becomes an important preventive measure to reduce the reintroduction of lymphatic filariasis or other controlled and silent infectious diseases.

\section{Venezuelans}

Venezuelan refugees are the current and unexpected concern for Brazilian health authorities. In January 2018 only, the country received around 800 individuals/day in the city of Pacaraima (state of Roraima), who were displaced to Boa Vista (capital of the state). So far, Brazil is believed to have received 40,000 illegal Venezuelan immigrants (Table 4).

The Department of Health of the state of Roraima confirmed, on 20 February 2018, that seven suspected cases of measles are under investigation. An 1-year-old Venezuelan child, with no vaccination history, had measles infection confirmed by the Oswaldo Cruz Foundation (Fiocruz) and local authorities 18. Of the seven cases (five boys and two girls, in the age group between 7 months and 10 years old), six are Venezuelan and one is Brazilian, residents in Boa Vista and with no history of vaccination. Measles was considered an infectious disease controlled in Brazil since 2015. Venezuela's political and economic crisis is believed to be the main reason for immigration to Brazil. 
Table 4

\begin{tabular}{lcc}
\begin{tabular}{l} 
Immigrants and refugees in Brazil: asylum claims by \\
country, 2016/2017. \\
\hline Country
\end{tabular} & $\mathbf{2 0 1 6}$ & $\mathbf{2 0 1 7}$ \\
\hline Venezuela & 3,375 & 17,865 \\
Cuba & 1,370 & 2,373 \\
Angola & 1,353 & 2,036 \\
Haiti & 646 & 2,362 \\
Syria & 391 & 2,746 \\
Democratic Republic of Congo & 382 & 1,102 \\
Nigeria & 326 & $\mathrm{NA}$ \\
China & 322 & 1,462 \\
\hline
\end{tabular}

NA: not available.

Source: Brazilian Ministry of Justice 23.

In January 2018 only, 150 Venezuelan pregnant women received childbirth care in Pacaraima. The number of childbirths (452 births in 2015; 810 births in 2016; 1,681 births in 2017) and the neonatal care at this border city increased in the last three years due to the migration flow from Venezuela 19.

Venezuelan refugees first seek medical care in Brazil, and then citizenship by naturalization as a consequence of the current immigration rules that grant parents this special concession.

\section{The difficult task to receive immigrants: recommendations and possibilities}

A massive plan which includes the refugees' registration, supply of adequate lodging and food services, hygiene program and mass vaccination for preventable infectious diseases are urgent to reduce the risks of outbreaks of controlled infectious diseases in the country.

We may infer this vulnerable condition of immigrants due to the measles outbreaks in the borders, previously cited, and the persistence of tetanus 20 , a controlled disease in some emerging countries such as Brazil, but still with high mortality rates of newborns in the main emissive countries such as poor regions of Africa and Asia 21

This low vaccination coverage and childbirths overloaded the local health systems in the border cities, which declared state of emergency and receive urgent assistance by the Federal Government 22 .

Current efforts are focused on public health policies, with direct investment in local public health clinics and vaccination for preventable infectious diseases (MMRV, influenza and others) to not compromise this group and the local population.

The emerging economies, such as Brazil, become an important destination for immigrants and refugees, receiving people from more distant countries and with poor origins (Table 4).

\section{Conclusion}

The current surveillance of migratory flows in emerging countries tends to become more complex, including not only the study of endemic infectious diseases from the emissive countries, but also the analysis and provision, if necessary, of healthcare assistance to this population near the borders, to avoid the reintroduction of some infectious diseases which are controlled in the host countries.

The continuous health support for these vulnerable communities should be established as a public health policy by all humanitarian nations, becoming a preventive measure for the containment of potential infectious diseases with difficult diagnosis or silent transmission and, as previously mentioned, a global strategy that protect immigrants, refugees and the host population. 


\section{Contributors}

D. M. Fujita contributed to the study design, writing and revision. F. S. Salvador and G. P. S. Damião contributed to the literature review and data collection. G. M. Figueiredo contributed to the data collection and study design. L. H. S. Nali contributed to the study design and revision.

\section{Additional informations}

ORCID: Dennis Minoru Fujita (0000-0003-04195338); Felipe Scassi Salvador (0000-0003-16060975); Giselle Pacífico Sartori Damião (0000-00022372-0559); Gerusa Maria Figueiredo (0000-00019657-9675); Luiz Henrique da Silva Nali (00000002-8365-9796).

\section{Acknowledgments}

The authors wish to acknowledge the assistance from the Federal Institute of Education, Science and Technology of São Paulo, the São Paulo Institute for Tropical Medicine, and the laboratories of Medical Research (LIM-49) and of Medical Parasitology (LIM-46)/University of São Paulo.
1. United Nations High Commissioner for Refugees. Figures at a glance. Statistical yearbooks. http://www.unhcr.org/figures-at-a-glance. html (accessed on 20/Feb/2018).

2. Wallace S, Young MET. Immigration versus immigrant: the cycle of anti-immigrant policies. Am J Public Health 2018; 108:436-7.

3. Vargas ED, Sanchez GR, Juárez M. Fear by association: perceptions of anti-immigrant policy and health outcomes. J Health Polit Policy Law 2017; 42:459-83.

4. Pescarini JM, Rodrigues LC, Gomes MGM, Waldman EA. Migration to middle-income countries and tuberculosis: global policies for global economies. Global Health 2017; 13:15.

5. Ministério da Justiça e Segurança Pública. Refúgio em números. Diagnóstico do sistema de refúgio. Brasília: Ministério da Justiça e Segurança Pública; 2017.

6. Santos FV. The inclusion of international migrants in Brazilian healthcare system policies: the case of Haitians in the state of Amazonas. Hist Ciênc Saúde-Manguinhos 2016; 23 : 477-94.

7. Martinez VN, Komatsu NK, De Figueredo SM, Waldman EA. Equity in health: tuberculosis in the Bolivian immigrant community of São Paulo, Brazil. Trop Med Int Health 2012; 17:1417-24.

8. Jerónimo P. Report on citizenship law: Brazil. San Domenico di Fiesole: European University Institute/Robert Schuman Centre for Advanced Studies/EUDO Citizenship Observatory; 2016.

9. Ministério das Relações Exteriores. Brazilian citizenship through naturalization. http:// camberra.itamaraty.gov.br/en-us/brazilian_ citizenship_through_naturalisation.xml (accessed on 02/May/2018).

10. Repórter Brasil. Bolivianos são a segunda maior população de imigrantes da capital paulista. http://www.ebc.com.br/noti cias/2015/07/bolivianos-sao-segunda-maiorpopulacao-de-imigrantes-da-capital-paulista (accessed on 04/Apr/2018).

11. Shikanai Yasuda MA, Sátolo CG, Carvalho NB, Atala MM, Ferrufino RQ, Leite RM, et al. Interdisciplinary approach at the primary healthcare level for Bolivian immigrants with Chagas disease in the city of São Paulo. PLoS Negl Trop Dis 2017; 11:e0005466.

12. Pinto PFPS, Neto FC, de Almeida Ribeiro MCS. Tuberculosis among South American immigrants in São Paulo municipality: an analysis in space and time. Int J Tuberc Lung Dis 2018; 22:80-5.

13. Borges FT, Muraro AP, da Costa Leão LH, de Andrade Carvalho L, Siqueira CEG. Socioeconomic and health profile of Haitian immigrants in a Brazilian Amazon State. J Immigr Minor Health 2018; 20:1373-9. 
14. Rawlinson T, Siqueira AM, Fontes G, Beltrão RPL, Monteiro WM, Martins M, et al. From Haiti to the Amazon: public health issues related to the recent immigration of Haitians to Brazil. PLoS Negl Trop Dis 2014; 8:e2685.

15. McCarthy WJ, Flores Y, Zheng H, Hanson TL. Immigrant generational status and ethnic differences in health. Am J Public Health 2005; 95:1494.

16. Nunes MRT, Faria NR, de Vasconcelos JM, Golding N, Kramer MU, de Oliveira LF, et al. Emergence and potential for spread of Chikungunya virus in Brazil. BMC Med 2015; 13:102.

17. Zuchi A, Prust LT, Rocha A, Araújo J, da Silva PS, Fiorillo K, et al. Screening and evaluation of lymphatic filariasis in immigrants from endemic countries residing in a focus where it is considered eliminated in the Southern Region of Brazil: a risk of reemergence? Acta Trop 2017; 176:192-6.

18. Secretaria de Estado da Saúde de Roraima. Sarampo: Sesau atualiza casos suspeitos e ações de combate. http://www.saude.rr.gov.br/ index.php/2017-04-30-22-46-19/noticias2/10-noticias-da-sesau/322/sarampo-sesauatualiza-casos-suspeitos-e-acoes-de-combate (accessed on 11/Apr/2018).
19. Secretaria de Estado da Saúde de Roraima Audiência Pública: Secretário de Saúde aborda imigração venezuelana na Câmara Municipal de Boa Vista. http://www.saude.rr.gov. br/index.php/2017-04-30-22-46-19/noticias -2/10-noticias-da-sesau/380/audiencia-publi ca-secretario-de-saude-aborda-imigracao-ve nezuelana-na-camara-municipal-de-boa-vista (accessed on 25/Apr/2018).

20. Dietz V, Milstien JB, van Loon F, Cochi S, Bennett J. Performance and potency of tetanus toxoid: implications for eliminating neonatal tetanus. Bull World Health Organ 1996; 74:619-28

21. Kyu HH, Mumford JE, Stanaway JD, Barber RM, Hancock JR, Vos T, et al. Mortality from tetanus between 1990 and 2015: findings from the global burden of disease study 2015. BMC Public Health 2017; 17:179.

22. Brasil. Síntese das ações de cada órgão do governo federal junto aos haitianos. http://www. brasil.gov.br/governo/2013/04/sintese-dasacoes-de-cada-orgao-do-governo-federal-jun to-aos-haitianos (accessed on 03/Apr/2018).

23. Ministério da Justiça. Refúgio em números. 3a Ed. https://www.acnur.org/portugues/wpcontent/uploads/2018/04/refugio-em-nume ros_1104.pdf (accessed on 06/Jun/2018). 